\title{
総合周産期医療施設における小肾集中治療室入室症例の現状 一小児特定集中治療室管理料制定の必要性について一
}

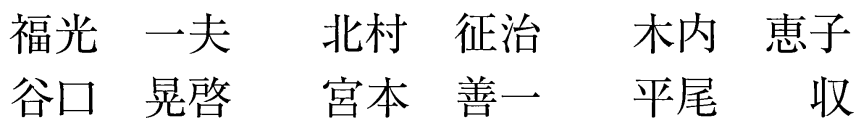

\begin{abstract}
要約：1997 年 1 月 1 日から 1999 年 12 月 31 日の 3 年間に当センター小児集中治療室 (PICU) に入室した 545 例の年齢別, 疾患別在室日数を調べた。平均年齢は 2.3 歳, 平均 PICU 在室日数 は 10.6 日であった。年齢別では新生児症例が全体の $19.6 \%$ 占め, 在室延日数の $45.1 \%$ 占め た。新生児症例のうち $27.1 \%$ は入院期間内にPICU に再入室していた。疾患別では左心低形成 症候群, 先天性横隔膜ヘルニア, 臍帯ヘルニアなどの先天性疾患で新生児手術症例の PICU 在 室期間が長かった。PICUに占める新生児症例の割合は,我が国での周産期医療の進歩とともに さらに増加すると推察された。診療報酬の試算結果では特定集中治療室管理料加算日数を現状 の 14 日から 21 日に延長し新生児症例については 60 日にすることで，PICU 在室延日数の $88 \%$ が加算対象となった。PICU不足問題に対して医療経済面からも効果を期待するためには, 加算 日数を大幅に増やした小児集中治療室算定基準を設ける必要がある。
\end{abstract}

Key words: (1) pediatric intensive care unit, (2) long-stay patients, (3) health insurance, (4) perinatal care

\section{はじめに}

我が国では周産期医療の発達がめざましく, 新生児・ 乳児の生存率が世界のトップクラスであることが良く 知られている。また政府主導の周産期医療対策事業も 開始され，今後もさらに発展していくものと予測され る。一方, 小児医療は整備が立ち遅れており, 1〜4歳 の小児は先進国との比較において死亡率が高いことも 明らかにされている1)。早期の解決が必要なテーマとし て, 小児救急医療・ 小児集中治療の充実が大きな課題 である。

医療経済の観点からは小児医療の社会保険診療報酬 増額への見直しが行われつつある。しかし小児集中治 療室（pediatric intensive care unit, PICU）を推進す る具体策は制定されておらず，特定集中治療室管理料 は小児と成人の区別なく算定されている。一方, 新生 児集中治療室 (neonatal intensive care unit, NICU) の 場合は新生児特定集中治療室管理料が制定されており, その算定日数の上限は21日であり超低出生体重児では 90 日まで認められている。外科的な治療目的などで PICUに览を収容する場合は, 新生児であっても成人の
特定集中治療室管理料算定日数と同一の上限 (14日)で ある点が医療経済面でも不合理と思われる。そこで今 回我々は, 周産期医療の基幹施設として 20 年以上経過 した当施設における PICU 入室症例の年齢構成, PICU 在室日数, 入院日数などの利用状況の解析を行い, 小 児集中治療の問題点を明らかにするとともに，特定集 中治療室管理料の算定日数について調査し検討を加え たので報告する。

\section{対象および方法}

特定集中治療室管理料の算定日数は一度の入院期間 中に14日が上限と規定されている。長期間入院して複 数回 PICU 入室を繰り返す症例の算定日数を把握する ために調査期間は3年間とした。PICU再入室症例の年 齢および診断名は初回 PICU 入室時点のものとし, 在 室日数は入院期間中総合計の日数とした。1997年 1 月 1 日から 1999 年 12 月 31 日の間に当施設 PICU に在室 した症例を対象とし, PICU入室患者データベースおよ び病院医事データベースから調査した。在室日数は(退 室日 - 入室日 +1) 日と計算した。調査期間を超えて在 室していた症例については, 調査期間中に限った日数 
を計上した。各症例の算定日数と, PICU在室日数が14 日を超えたために特定集中治療室管理料が算定できな かった日数（非算定日数）を年齢および疾患別に集計 した。統計学的処理はカイ 2 乗検定または MannWhitney 検定を用い， $P<0.05$ を有意とした。

\section{結果}

期間中にPICUに入室した症例は545例であった。そ のうち 65 例 $(11.9 \%)$ はPICUに再入室しており，そ の平均再入室回数は 1.5 回であった。 545 例の平均年齢 は2.3歳であり, 年少児が多かった。PICUの平均在室 日数は 10.6 日であった。人工呼吸は 450 例 $(82.6 \%)$ に 施行し, その平均人工呼吸日数は 6.6 日であった。体外 膜型肺は 4 例, 血液透析療法 8 例, 腹膜透析療法 19 例, 一酸化窒素吸入療法は78例に施行した。心臓血管外科 283 例，小児一般外科 155 例，脳神経外科 8 例，その 他の外科 44 例など, 外科症例の入室が多く, 全体の 89.9 \%を占めた（Table 1)。

疾患別では特に左心低形成症候群，先天性横隔膜へ ルニア，臍帯ヘルニア，食道閉鎖症など新生児期に侵 襲の大きな手術を行った症例の在室日数が長く, PICU に再入室した頻度も高かった（Table 2)。また，これ らの疾患群の平均人工呼吸日数はそれぞれ 32.1 日, 31.8 日，23.0日，15.2 日であり，入室期間中の大部分で人 工呼吸療法を行っていた。対象の PICU 退室時転帰が 死亡であったのは 24 例 $(4.4 \%)$ であった。
生後 28 日未満の新生児期にPICUに入室した症例 (新 生児症例）は 107 例 (19.6\%), 在室延日数は 2,580 日 $(44.6 \%)$, 平均在室日数 24.1 日であった。生後 28 日以 上の症例 (年長巟症例) の平均在室日数は 7.3 日であっ た。新生児症例の入院日数は年長児症例に比べて有意 に長かった。PICU再入室症例数は新生児症例で 29 例 $(27.1 \%)$ と多く, 年長児症例で少なかった（Table 3)。 特定集中治療室管理料の算定日数については, 新生览 症例の在室延日数のうち 1,458 日（56.5\%）が非算定日 数であった。生後 28 日以上 1 歳未満の乳児の非算定日 数は $23.3 \%, 1$ 歳以上 3 歳未満は $16.9 \%, 3$ 歳以上の症 例では $9.8 \%$, 年長であるほど非加算日数は少なかっ た (Fig. 1)。

\section{考察}

当施設は総合周産期医療施設として全国に先駆け 1981 年 10 月設立され, 現在は産科・新生児科の周産期 部門 (160 床) と小児診療部門 (203 床) の 2 部門で構 成されている。PICU は小児診療部門のなかで運営さ れ，1992 年以来，特定集中治療室 6 床の施設認定を受 けている。集中治療専門医が管理責任者となり複数の 専門診療科の連携によって重症患児の治療が行われて いる。

今回の結果から PICU 入室患者の年齢構成が他の報 告 2),3) と比較して年少症例が多いことが明らかであっ た。Marcinらがまとめたデータベースによる北米32カ

Table 1 Patient characteristics and the length of PICU stay

\begin{tabular}{lc}
\hline \hline Number of patients & 545 \\
Age & 2.3 years \\
mean & 1.2 years $(0$ day $\sim 16.8$ years $)$ \\
median (range) & 56.1 \\
Male (\%) & 89.9 \\
Surgical patients $(\%)$ & \\
Therapeutic modalities (\%) & 82.6 \\
Artificial ventilation & 0.7 \\
ECMO & 1.5 \\
Hemodialysis & 3.4 \\
Peritoneal dialysis & 14.3 \\
Inhalation of nitric oxide & \\
PICU stay (days) & 10.6 \\
mean & $6(1 \sim 203)$ \\
median (range) & 11.9 \\
Re-admission (\%)* & \\
Hospital stay (days) & 89.0 \\
mean & $43 \sim 1,095)$ \\
median (range) &
\end{tabular}

ECMO, extracorporeal membrane oxygenation; *, percent of patients re-admission to PICU during the same hospitalization. 
Table 2 Primary diagnosis and the length of PICU stay

\begin{tabular}{lccc}
\hline \hline Primary diagnosis & Number of patients & Number of re-admission * & Mean days in PICU (median, range) \\
\hline HLHS & 7 & $6(86 \%)$ & $70.7(64,31 \sim 130)$ \\
CDH & 20 & $5(25 \%)$ & $34.8(23,8 \sim 203)$ \\
Omphalocele & 6 & $2(33 \%)$ & $33.0(27,4 \sim 64)$ \\
TEF & 11 & $3(27 \%)$ & $27.5(12,2 \sim 100)$ \\
CAVC & 7 & $2(29 \%)$ & $20.0(13,2 \sim 51)$ \\
TAPVR & 4 & $1(25 \%)$ & $18.0(14,8 \sim 41)$ \\
TGA & 22 & $5(23 \%)$ & $15.0(11,3 \sim 51)$ \\
CoA & 9 & $2(22 \%)$ & $13.7(16,7 \sim 44)$ \\
PAIVS & 12 & $2(17 \%)$ & $12.8(8,3 \sim 81)$ \\
SV & 25 & $2(8 \%)$ & $12.8(11,2 \sim 26)$ \\
DORV & 16 & $3(19 \%)$ & $11.0(9,3 \sim 42)$ \\
VSD & 70 & $2(3 \%)$ & $7.2(5,2 \sim 43)$ \\
TOF & 44 & 0 & $7.2(6,2 \sim 22)$ \\
GER & 39 & $4(10 \%)$ & $5.0(4,1 \sim 36)$ \\
ASD & 27 & 0 & $5.0(3,2 \sim 11)$ \\
\hline
\end{tabular}

HLHS, hypoplastic left heart syndrome; CDH, congenital diaphragmatic hernia; TEF, tracheo-esophageal fistula; CAVC, common atrio-ventricular canal; TGA, transposition of the great arteries; CoA, coarctation of the aorta; PAIVS, pulmonary atresia with intact ventricular septum; SV, single ventricle; DORV, double outlet right ventricle; VSD, ventricular septal defect; TOF, tetralogy of Fallot; GER, gastroesophageal reflux; *, number of patients re-admission to PICU during the same hospitalization.

Table 3 Patient age and the length of PICU stay

\begin{tabular}{lccc}
\hline \hline & Age $<28$ days $(\mathrm{N}=107)$ & 28 days $\leqq$ age $(\mathrm{N}=438)$ & $P$ value \\
\hline PICU stay (days) & 24.1 & 7.3 & $<0.05$ \\
mean & $14(1 \sim 203)$ & $5(1 \sim 81)$ & $<0.05$ \\
median (range) & 27.1 & 8.2 & $<0.05$ \\
Re-admission (\%) & 100.0 & 86.3 & \\
Hospital stay (days) & $68(10 \sim 517)$ & $10(1 \sim 1,095)$ & \\
mean & &
\end{tabular}

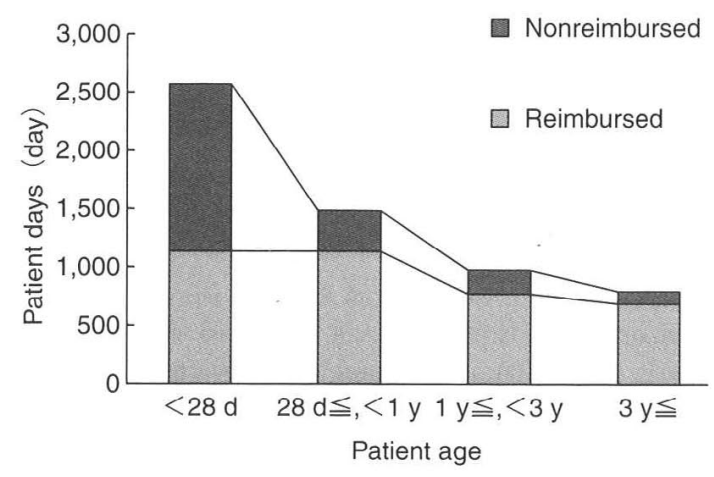

Fig. 1 Age groups and the number of patient days reimbursed by the Japanese health insurance system. Fifty-six percents of patient days in the age group under 28 days were not reimbursed.
所のすべての PICU 入室患者平均年齢（3.7～ 7.9 歳） 4 ) より当施設の平均年齢が若かった。また新生児症例の 在室延日数が PICU 在室延日数全体の半数近い割合を 占めたことが特徽的であった。

新生児症例が多かった理由として, 当施設が周産期 医療の拠点病院であることが一因と推察される。周産 期部門のNICUは当初から未熟児治療を主として抢り， 周産期医療体制の整備とともに次第に高度に専門化し てきた。そのため, 現在では未熟性に基づく疾患を合 併しない新生児を収容することは少なくなっている。 一方, PICUは先天性心疾患の呼吸循環管理や出生後早 期から外科処置などを必要とする重症新生児を収容し, 病態に応じた小児部門各科の専門家が複数参加するこ とで治療が効率良く行われている。重症新生児を NICUとPICUのどちらに収容するかの基準は厳密には 
定められてはいないが，主に未熟性の程度で判断され る。例えば，先天性横隔膜へルニア症例の場合は出生 体重 $1,800 \mathrm{~g}$ 以上かつ在胎週数 35 週以上であればPICU に収容している。PICUに収容する新生児症例は今回の 集計結果が示すように治療期間が長く, PICU再入室の 頻度も高い。結果として PICU で新生览症例の占める 割合が高くなっていたと思われる。

我が国では 1996 年に人口 100 万人に 1 力所の総合周 産期センター設置の構築を目標とした厚生労働省の周 産期医療対策事業総合周産期認定病院制度が導入され， 全国に NICU，母体・胎児集中治療室が整備されつつ ある。胎児診断技術も向上し，出生前から緻密な治療 計画が行われ，これまで生存しえなかった重症例も救 命できるようになった。周産期医療の発垟によって小 児医療のなかで新生児の占める割合が明らかに大きく なっている5)。新生児がPICUの病床を占める割合が大 きくなれば，本来 PICU に収容すべき小児症例が入室 できない事態も起こる。近年，小児救急を含めた小児 医療に刘する整備の必要性が強く求められているが, その大きな支えとなるべきPICU の不足について再認 識されるべきである。

本来であればPICU在室日数はfast-trackの方向であ って短縮するものと思われる。例えば心房中隔欠損症， 心室中隔欠損症，大血管転移症，ファロー四徵症など 先天性心疾患の根治手術も, 低侵襲の術式, 早期抜管, 短期間のPICU在室の傾向である61,7)。しかし一方では, 左室低形成症候群, 総肺静脈還流異常症, 総動脈管症 などの症例や，術前から呼吸循環不全のあった症例な どは今後も慎重でなければならないとされている8)。呼 吸器系や循環器系の先天的な臟器形成不全を合併して 出生した患児の場合は，自立して生存するために長期 間の PICU 在室は不可避と思われる。すなわち新生児 症例の PICU 在室期間の短縮は今後も困難であると推 察される。

P I C U の重要性についてはよく知られている。 Pearson らは，一般 ICU のなかで小児を扱った場合の 死亡数は重症度を補正しても専門のPICUに比べて2倍 以上であったと報告している9。また小览の場合は, 単 に生存率の向上以外に多くのものが求められる。重い 疾患を負った子供が後遺症なく生存し，人的資源とし て社会に向けて成育させる環境が必要である。そのた めには子供の発達・心理面のケアについても集学的に フォローアップできる体制を持つ PICU の増床が必要 である。
PICU不足を解決する1つの手段として診療報酬体制 を見直すことは有効と思われる。特定集中治療室管理 料の加算の有無については，その加算ができない場合 の医事請求額が入院加算料, 検査, 投薬などの合計で も加算可能時の約半額となるため, 医療経済面での影 響が大きい。小児特定集中治療室管理料を設けた場合 を想定して，今回の PICU 入室者データ上で試算した 結果では, 加算日数上限を NICU と同一の 21 日に延長 し，新生児については 60 日とすることで, 各年齢群の 加算日数をほぼ均等に割増することが可能になる。在 室日数に対する加算日数割合の具体的な変化としては, 新生児症例で $44 \%$ が $87 \%$ になり, 生後 28 日以上 1 歳 未満の乳児で $77 \%$ が $87 \%$ に，1歳以上の症例では $89 \%$ となり, PICU 全延在室日数の $88 \%$ がカバーされるこ とになる。病院管理者の PICU 設立や増床への関心を 高めるためには，この程度十分な算定基準を設けるこ とが妥当と思われる。

以上, 当施設のPICU入室症例の現状を報告し, PICU 運営上の問題点について述べた。PICUの整備推進をは かるためには小児特定集中治療室管理料を設けて，成 人のICUの一部として小児集中治療を行う体制とは医 療経済面でも明確に区別することが望まれる。

本稿の要旨は第 28 回日本集中治療医学会総会 $(2001$ 年, 東京）において発表した。

\section{文 献}

1) 田中哲郎. 我が国の小児救急医療体制の現状と今後の整備. 周産期医学 2002; 32: 612-6.

2) Dominguez TE, Chalom R, Costarino AT Jr. The impact of adverse patient occurrences on hospital costs in the pediatric intensive care unit. Crit Care Med 2001; 29: 169-74.

3) Pon S, Notterman DA, Martin K. Pediatric critical care and hospital costs under reimbursement by diagnosis-related group: effect of clinical and demographic characteristics. J Pediatr 1993; 123: 355-64.

4) Marcin JP, Slonim AD, Pollack MM, et al. Long-stay patients in the pediatric intensive care unit. Crit Care Med 2001; 29: 652-7.

5) 藤村正哲.これからの新生児外科一周産期医療の視点. 日小 外会誌 1997; 33: 38-42.

6) Marianeschi SM, Seddio F, McElhinney DB, et al. Fast-track congenital heart operations: a less invasive technique and early extubation. Ann Thorac Surg 2000; 69: 872-6.

7) Vricella LA, Dearani JA, Gundry SR, et al. Ultra fast track in elective congenital cardiac surgery. Ann Thorac Surg 2000; 69: 865-71.

8) Lake CL. Fast tracking the paediatric cardiac surgical patient. Paediatr Anaesth 2000; 10: 231-6.

9) Pearson G, Shann F, Barry P, et al. Should paediatric intensive care be centralized? Trent versus Victoria. Lancet 1997; 349: 1213-7. 
Abstract

Health insurance system and the length of stay in a pediatric intensive care unit

Kazuo Fukumitsu, Seiji Kitamura, Keiko Kinouchi, Akihiro Taniguchi, Yoshikazu Miyamoto, Osamu Hirao

Department of Anesthesiology, Osaka Medical Center and Research Institute for Maternal and Child Health

840 Murodo-cho, Izumi, Osaka 594-1101, Japan

We examined the length of stay of 545 patients admitted to the pediatric intensive care unit (PICU), Osaka Medical Center and Research Institute for Maternal and Child Health from January 1, 1997 to December 31, 1999. The mean age of the patients was 2.3 years (range, 0 day 16.8 years). Mean stay in PICU for all patients was 10.6 days (range, $1 \sim 203$ days), and the total patient days of PICU were 5,787 days. Patients younger than the age of 28 days (neonates) comprised $19.6 \%$ of the PICU patients and occupied $45.1 \%$ of the total patient days. Of the neonates, 29 cases $(27.1 \%)$ were re-admitted to PICU during the same hospitalization. Patients diagnosed with congenital anomalies complicated by severe organ insufficiency, including hypoplastic left heart syndrome, congenital diaphragmatic hernia or omphalocele, needed long PICU stays. Fifty-six percentages of PICU stays of the neonates were not reimbursed by the Japanese health insurance system for the intensive care unit (ICU). Reimbursement for the charges of ICU stay was predetermined to 14 days, however, according to provisional estimates, children and neonates admitted to our PICU required 21 days and 60 days, respectively. We reported the present situation of the PICU in a perinatal center. With the perinatal care progress, neonates will occupy a large fraction of PICU beds. Reform of the health insurance system should be considered to improve pediatric intensive care.

Key words: (1) pediatric intensive care unit, (2) long-stay patients, (3) health insurance, (4) perinatal care

J Jpn Soc Intensive Care Med 2003; 10: 99 103 